Отич Олена Миколаївна доктор педагогічних наук, професор, професор кафедри авіаційної психології Національного авіаційного університету, просп. Любомира Гузара, 1, м. Київ, 03058, тел.: (097) 719-21-77, https://orcid.org/0000-0003-2686-2832

\title{
ОСОБИСТІСНО-ДІЯЛЬНІСНИЙ ПІДХІД ДО ПРОФЕСІЙНОЇ САМОРЕАЛІЗАЦЇ̈ НАУКОВО-ПЕДАГОГІЧНИХ ПРАЦІВНИКІВ
}

Анотація. Професійна самореалізація особистості $є$ метою й водночас найвищою точкою іiі професійного розвитку. Для працівників освітньої галузі вона пов'язується 3 досягненням педагогічної майстерності, викладацької досконалості, високого професіоналізму, складовими яких є професіоналізм особистості, професіоналізм діяльності та професіоналізм фахового самовдосконалення.

3 огляду на тісний взаємозв'язок зовнішнього (діяльнісного) i внутрішнього (особистісного) аспектів у професійній самореалізації особистості, актуалізується необхідність застосування особистісно-діяльнісного підходу до вивчення психологічних особливостей професійної самореалізації науково-педагогічних працівників.

Цей підхід грунтується на ідеї нерозривного взаємозв'язку особистості й діяльності, який виявляється в тому, що особистість, з одного боку, є суб'єктом діяльності, а з іншого - формується і розвивається в діяльності. Отже, для того, щоб досягти максимальної самореалізації у професії, людині потрібно враховувати свої особистісні якості і здібності, співвідносити їх із вимогами професійної діяльності й постійно удосконалювати свій професіоналізм.

Професійна самореалізація науково-педагогічних працівників зумовлюється поєднанням в їхній професійній діяльності наукового, освітнього, комунікативного i управлінського аспектів. Відповідно до спрямованості науково-педагогічних працівників на один 3 цих аспектів, виокремлюються їх типи: педагог-науковець, педагог-дидакт, педагогметодист, педагог-менеджер. Крім того, на тип професійної самореалізації науково-педагогічних працівників впливає спрямованість на предмет (предметоцентризм), на студентів (студентоцентризм), на себе (егоцентризм).

Розуміння особистісних детермінант професійної самореалізації науковопедагогічних працівників дозволяс управляти цим процесом і здійснювати його моніторинг, як співвідносячи 3 певним професійним стандартом, так i виявляючи ступінь актуалізації їхнього особистісного потенціалу в професійній діяльності. 
Ключові слова: професійна самореалізація, особистісно-діяльнісний підхід, спрямованість, типологізація, професійно важливі якості, здібності, професіоналізм діяльності.

Otych Olena Mykolaivna Doctor of Pedagogical Sciences, Professor, Professor of chair of Aviation Psychology, National Aviation University, Lubomir Husar Ave., 1, Kyiv, 03058, tel.: (097) 719-21-77, https://orcid.org/0000-0003-2686-2832

\section{PERSONAL-ACTIVE APPROACH TO PROFESSIONAL SELF- REALIZATION OF SCIENTIFIC AND PEDAGOGICAL WORKERS}

Abstract. Professional self-realization of the individual is the goal and at the same time the highest point of his professional development. For educators, it associated with the achievement of pedagogical skills, teaching excellence, high professionalism, which include professionalism of personality, professionalism of activity and professionalism of professional self-improvement.

Given the close relationship between external (activity) and internal (personal) aspects in the professional self-realization of the individual, the need for a personalactivity approach to the study of psychological characteristics of professional selfrealization of research of teaching staff.

This approach is based on the idea of the inseparable relationship between personality and activity, which is manifested in the fact that the individual, on the one hand, is the subject of activity, and on the other - is formed and developed in activity. Thus, in order to achieve maximum self-realization in the profession, a person needs to take into account their personal qualities and abilities, relate them to the requirements of professional activity and constantly improve their professionalism.

Professional self-realization of scientific and pedagogical workers is conditioned by a combination of scientific, educational, communicative and managerial aspects in their professional activity. According to the orientation of scientific and pedagogical workers on one of these aspects, their types are distinguished: teacher-scientist, teacher-didactic, teacher-methodologist, teacher-manager. In addition, the type of professional self-realization of research and teaching staff is influenced by the focus on the subject (subject-focused), students (student-focused), self (ego-focused).

Understanding the personal determinants of professional self-realization of scientific and pedagogical workers allows to manage this process and monitor it, both in relation to a certain professional standard and revealing the degree of actualization of their personal potential in professional activities.

Keywords: professional self-realization, personal-activity approach, orientation, typology, professionally important qualities, abilities, professionalism of activity.

Постановка проблеми. Професійна самореалізація особистості є метою й водночас найвищою точкою iï професійного розвитку - акме професіонала, 
тобто вершиною, на якій максимально повно розкриваються його особистісний і професійний потенціали й реалізуються його професійно важливі якості (до того ж таким чином, що і він сам й оточуючі відчувають задоволення від процесу та результатів цієї реалізації).

Для працівників освітньої галузі стан найвищої професійної самореалізації пов'язується 3 досягненням педагогічної майстерності, викладацької досконалості, високого професіоналізму, складовими яких $є$ професіоналізм особистості (найвищий рівень розвитку професійно важливих особистісних якостей і спеціальних здібностей), професіоналізм діяльності (найвищий рівень оволодіння змістом діяльності й професійними операціями, сформованість професійної компетентності) та професіоналізм фахового самовдосконалення (спрямованість на неперервний професійний розвиток і досягнення найвищих результатів у професіi).

3 огляду на те, що дослідження феномену професійної самореалізації передбачає його розгляд у взаємодії зовнішнього (діяльнісного) і внутрішнього (особистісного) аспектів, актуалізується необхідність застосування особистісно-діяльнісного підходу до вивчення психологічних особливостей професійної самореалізації науково-педагогічних працівників.

Цей підхід грунтується на ідеї нерозривного взаємозв'язку особистості й діяльності, який виявляється в тому, що особистість, з одного боку, є суб'єктом діяльності, а з іншого - формується і розвивається у діяльності. Отже, для того, щоб досягти максимальної самореалізації у житті й професії, людині потрібно враховувати свої особистісні якості і здібності, співвідносити їх із вимогами професійної діяльності й постійно удосконалювати свій професіоналізм.

\section{Аналіз останніх досліджень і публікацій.}

Проблемі професійної самореалізації науково-педагогічних працівників присвятили свої праці С. Барбіна, С. Безбородих, О. Коваленко, А. Кузьмінський, Н. Лосева, В. Луговий, О. Михальчук, I. Ніколаєску, В. Рибалка, Н. Степанова та інші психологи й педагоги.

3 позицій особистісно-діяльнісного підходу цю проблему досліджували науковці школи педагогічної майстерності академіка І. Зязюна: Н. Базилевич, I. Кривонос, Л. Малаканова, Н. Пивовар, В. Семиченко, Н. Тарасевич, А. Ткаченко та ін.

Розглядаючи професійну самореалізацію педагога як неодмінну умову особистісної самореалізації його вихованців, представники школи І. Зязюна приділяли особливу увагу в цьому процесі професійній i особистісній спрямованості викладача, його професійній компетентності, педагогічним здібностям та педагогічній техніці як найголовнішим елементам у структурі педагогічної майстерності [3; 4; 5; 6; 7].

Водночас, попри вагомі здобутки науковців у дослідженні різних аспектів професійної самореалізації педагогів, до цього часу недостатньо розкритим залишився потенціал особистісно-діяльнісного підходу у розробленні проблеми 
професійної самореалізації науково-педагогічних працівників, яка має свої особливості порівняно із самореалізацією у професії учителів закладів загальної середньої освіти та інших працівників освітньої галузі.

Мета статті - грунтуючись на особистісно-діяльнісному підході, розкрити особистісні детермінанти професійної самореалізації науковопедагогічних працівників.

Виклад основного матеріалу. Розгляд проблеми професійної самореалізації особистості 3 позицій особистісно-діяльнісного підходу передбачає виявлення іï взаємозв’язку із професійним розвитком фахівця, реалізацією його особистісного потенціалу, професійною самоідентифікацією, професійною рефлексією тощо [2, с. 83]. При цьому слід виходити 3 того, що професійна самореалізація виступає одночасно і як досягнення соціально значущих результатів у професійній діяльності і як неперервне професійне самовдосконалення особистості, спрямоване на розвиток професійно важливих якостей та професійних компетентностей [2, с. 83].

Діяльнісний аспект особистісно-діяльнісного підходу реалізується у визнанні професійної самореалізації найвищою стадією професійного розвитку людини як суб'єкта професійної діяльності, що характеризує рівень актуалізації iii потенційних можливостей у цій діяльності і пов'язується 3 високою продуктивністю праці, кар'єрним зростанням, стійким попитом інших професіоналів на професійну кваліфікацію, досвід та досягнення фахівця $[1 ; 2]$.

Особистісний аспект особистісно-діяльнісного підходу пов'язується із розумінням професійної самореалізації як розкриття особистісного потенціалу людини, iii особистісного самоздійснення у професійній діяльності, що підкреслює особистісний смисл цього процесу. У зв’язку з цим набувають важливості такі аспекти професійної самореалізації фахівця, як прояв ним високого рівня свободи й творчості у професійній діяльності, задоволеність іiі процесом та результатами тощо $[1 ; 2]$.

Взаємозв'язок особистісного й діяльнісного аспектів особистіснодіяльнісного підходу виявляється у визначенні особистісних детермінант успішної професійної самореалізації людини, а саме:

наявності в неї вираженої потреби у постійному професійному вдосконаленні;

- існуванні проєкту власного професійного розвитку;

- домінуванні спрямованості на досягнення визначених професійних цілей над задоволеністю власними професійними здобутками;

формуванні власного професійного простору та ін. [8].

Для науково-педагогічних працівників вплив цих детермінант опосередковується особливостями їхньої професійної діяльності, яка поєднує в собі освітній, науковий, комунікативний та управлінський аспекти. 
Перший реалізується як дидактичний вплив викладача закладу вищої освіти на студентів 3 метою формування в них системи професійних знань та здатності відповідати кваліфікаційним вимогам і компетентностям, визначеним освітньою програмою. А це потребує достатнього розвитку таких особистісних якостей науково-педагогічних працівників, які зумовлюють успішність викладацької діяльності: аналітичного й критичного мислення, стрункої логіки, виразного мовлення, проєктивних умінь, що дозволяють відбирати й структурувати зміст дисципліни, планувати порядок його викладання, добирати найбільш доцільні форми і методи навчання (свого викладання та учіння студентів).

Усвідомлення важливості цих складових дидактичного процесу в сучасній європейській освіті виявилося у розробленні та активному впровадженні освітніх програм, зміст яких спрямовується на такий аспект професійної самореалізації, як досягнення досконалості викладацької діяльності науковопедагогічних працівників.

Другий, науковий, аспект професійної діяльності викладача вищої школи полягає в зумовленості освітньої діяльності науковою як базовою, оскільки зміст освіти у вищій школі традиційно будується на основі наукових досліджень науково-педагогічних працівників, а в умовах модернізації вищої освіти орієнтується на інтеграцію освіти, науки та виробництва (бізнесу) як пріоритетний напрям освітніх змін, відображених у тріаді «наука - вища освіта - інновації». Такий взаємозв’язок передбачає не лише активне упровадження освітніх інновацій у вищій школі, а й усвідомлення значення вищої освіти як реальної продуктивної сили, яка запускає механізми трансформації світової економіки в економіку знань. Це вимагає від викладачів вищої школи розвитку таких особистісних якостей як підприємливість, креативність, гармонійність теоретичного і практичного інтелекту тощо.

Особливої актуальності ці якості набувають сьогодні, коли заклади вищої освіти вступають у жорстку конкурентну боротьбу за випускників шкіл, в якій нерідко перемагає не об'єктивно найсильніший університет, а той, чиї науковопедагогічні працівники можуть 3 максимальною ефективністю налагодити зв'язки із зовнішньою громадськістю i створити позитивний імідж свого закладу вищої освіти.

Комунікативний аспект науково-педагогічної діяльності актуалізує професійну роль викладача вищої школи як комунікативного лідера, який володіє переконливим мовленням, є атрактивним для своїх студентів, може «закохати» їх у свій предмет й запалити пізнавальний інтерес до його поглибленого самостійного вивчення. Це вимагає поєднання зовнішньої привабливості викладача як комунікатора 3 його внутрішньою притягальністю (педагогічним магнетизмом).

Перша належить до сфери педагогічної естетики і виявляється у таких професійно важливих якостях викладача, як почуття міри, смак, гармонійність, 
автентичність, конгруентність тощо. Друга стосується педагогічної етики i гуманістичного потенціалу викладача, адже студентів приваблює не лише високий професіоналізм, але й людські якості викладача: доброта, співчутливість, емпатійність, надійність, фасилітативність, віра в людину та інші гуманістичні якості педагога, які перетворюють його з «просто викладачапредметника» на «вчителя життя». I це, на нашу думку, є найвищим виявом професійної самореалізації науково-педагогічних працівників у комунікативній площині.

Звертаючись до управлінського аспекту науково-педагогічної діяльності, слід виходити передусім 3 того, що за своєю психологічною сутністю вона $\epsilon$ мета-діяльністю [4, 17-18], тобто діяльністю з рефлексивного управління самостійною навчальною діяльністю студентів (їх учінням) і саме від цього залежить іi ефективність, адже, виходячи зі структури навчання (викладання+учіння), навчити студента викладачеві самому неможливо, оскільки, якщо викладання є, а учіння не відбувається, то не відбувається й навчання і викладач лише даремно витрачає час, намагаючись вкласти у голови студентів свої наукові відкриття, переведені у певний формат змісту освіти.

До того ж освітній процес є не лише дією викладача, але й взаємодією його зі студентом чи студентською групою, тобто суб'єкт-суб'єктним процесом [5, 11-12]. I викладач у цьому процесі має управляти й навчальною діяльністю студентів, $\mathrm{i}$ їхньою увагою, емоціями, поведінкою тощо.

В умовах переходу на дистанційне навчання, спричиненого світовою пандемією COVID-19, цей процес стає ще більш складним i менш контрольованим, адже викладачеві дуже важко управляти освітньою взаємодією зі студентами, які ховаються за «чорними квадратами» чи «аватарками» в Zoom або Google Meet i педагоги часто не відчувають або втрачають зворотний зв'язок із ними під час лекції чи практичного заняття.

Рефлексивне управління навчальною діяльністю студентів вимагає від науково-педагогічних працівників, окрім рефлексивності, таких професійно важливих якостей особистості, як організованість, дисциплінованість, чіткість мовлення і дій, вимогливість, особистісна впливовість, сугестивність.

Наскрізними професійно важливими якостями науково-педагогічних працівників, які виступають особистісними детермінантами їхньої професійної самореалізації, є: спрямованість, життєва позиція особистості, переконання, ціннісні орієнтації тощо. Вони можуть стосуватися кожного 3 аспектів науковопедагогічної діяльності і, об’єднуючись навколо одного з них як домінантного, утворювати певний особистісний тип професійної самореалізації викладача вищої школи.

Наприклад, якщо узяти за основу спрямованість, то можна, на нашу думку, виокремити наукову, дидактичну, методичну та нормативну спрямованість діяльності й особистості науково-педагогічних працівників. 
Наукова спрямованість виявляється у наданні педагогом переваги науководослідній та публікаційній діяльностям перед іншими аспектами науковопедагогічної діяльності. Професійна самореалізація такого викладача відбувається як науковий пошук, результати якого упроваджуються у навчальні курси, які викладаються науково-педагогічним працівником, та розвиваються у діяльності його наукової школи, студентських наукових товариств чи гуртків. Це - педагог-науковець, вчений-очільник наукової школи.

Дидактична спрямованість діяльності викладача вищої школи детермінує його захопленість викладацькою діяльністю, прагнення досягти у ній найвищих результатів і черпати творчі сили в освітній i комунікативній взаємодії зі студентами. Це - педагог-дидакт, викладач-професіонал, педагог-майстер.

Методична спрямованість передбачає постійне експериментування викладача з формами, методами і технологіями викладання у вищій школі, розробленням педагогічних інновацій та методичних прийомів. Такий викладач отримує професійну самореалізацію у процесі накопичення і поширення свого досвіду викладання навчальних курсів, супервізіі, опікування молодими викладачами, обміну досвідом викладання і кращими освітніми практиками 3 колегами. Це - педагог-метолист, викладач-інноватор, наставник молоді.

Нормативна спрямованість характерна для науково-педагогічних працівників, які посідають чи прагнуть посісти керівні посади в університеті. Вони реалізуються не стільки в науковій, освітній чи методичній діяльностях, скільки в їх організації, адмініструванні чи стратегічному управлінні закладом. А це вимагає досконалого знання організаційної психології, психології управління, документознавства, умінь ведення документаціі, компетентності у застосуванні законодавчих актів i нормативно-правових документів, грамотного планування й оформлення звітів за результатів освітньої і наукової діяльностей тощо. Головне, щоб у цьому процесі документація не ставала самоціллю й не перетворювала нормативну спрямованість науковопедагогічного працівника на бюрократичну. Це - педагог-менеджер, адміністратор, організатор освітньо-наукового процесу.

Деталізуючи типологію особистісної спрямованості науково-педагогічних працівників, можна виділити також спрямованість на предмет (предметоцентризм), на студентів (студентоцентризм), на себе (егоцентризм), що детермінують відповідний тип їхньої професійної самореалізації.

Висновки. Отже, у контексті особистісно-діяльнісного підходу професійна самореалізація є найвищою стадією професійного розвитку людини як суб'єкта професійної діяльності й водночас формою іiі особистісного самоздійснення у цій діяльності.

Особистісними детермінантами професійної самореалізації людини виступають: наявність в неї вираженої потреби у постійному професійному вдосконаленні; існування проєкту власного професійного розвитку; домінування спрямованості на досягнення визначених професійних цілей над 
задоволеністю власними професійними здобутками; формування власного професійного простору [1].

Для науково-педагогічних працівників вплив цих детермінант опосередковується особливостями їхньої професійної діяльності, яка поєднує в собі освітній, науковий, комунікативний і управлінський аспекти.

Наскрізними професійно важливими якостями науково-педагогічних працівників, які виступають особистісними детермінантами їхньої професійної самореалізації, є: спрямованість, життєва позиція особистості, переконання, ціннісні орієнтації тощо. Вони стосуються кожного 3 аспектів науковопедагогічної діяльності. Об'єднуючись навколо одного з них як домінантного, вони утворюють певний особистісний тип професійної самореалізації викладача вищої школи: науковий, дидактичний, методичний, нормативний.

Розуміння особистісних детермінант професійної самореалізації науковопедагогічних працівників дозволяє управляти цим процесом і здійснювати його моніторинг, як співвідносячи 3 певним професійним стандартом, так i виявляючи ступінь актуалізації їхнього особистісного потенціалу в професійній діяльності.

\section{Лimepamypa:}

1. Кравчук C.M. (2015) Професійна самореалізація особистості як соціальнопсихологічний феномен. Актуальні проблеми психологї. Том V. Вип. 15. С. 82-92.

2. Кузьмина Н.В., Кухарев Н.В. (1976) Психологическая структура деятельности учителя. Гомель, С. 20.

3. Основы педагогического мастерства (1989) И.А. Зязюн, Л.В. Крамущенко, И.Ф. Кривонос и др. М.: Просвещение. 302 с.

4. Отич О.М. (2014) Основи педагогічної майстерності викладача професійної школи: підруч. Кіровоград : Імекс-ЛТД. 208 с.

5. Педагогічна майстерність (1997) підруч. І. А. Зязюн, Л. В. Крамущенко, I. Ф. Кривонос та ін.; за ред. І. А. Зязюна. К.: Вища школа. 349 с.

6. Педагогічна майстерність (2008) підруч. І. А. Зязюн, Л. В. Крамущенко, І. Ф. Кривонос та ін.; за ред. І. А. Зязюна. 3-тє вид., доп. і перероб. К.: СПД Богданова А. М. 376 с.

7. Педагогічна майстерність (2008) хрестоматія: навч. посібник I. А. Зязюн, Н. Г. Базилевич, Т. Г. Дмитренко та ін.; за ред. І. А. Зязюна. 3-тє вид., доп. і перероб. К.: СПД Богданова А. М. 462 с.

8. Профессиональная самореализация личности. Сайт Персонал-Престиж. [Электронный pecypc]. Режим доступа: https://персонал-престиж.pф/\%D0\%BF\%D1\%80\% D0\%BE\%D1\%84\%D0\%B5\%D1\%81\%D1\%81\%D0\%B8\%D0\%BE\%D0\%BD\%D0\%B0\%D0\%BB\%D1/

\section{References:}

1. Kravchuk S.M. (2015). Profesiyna samorealizacia osobistosti yak socialno-psychologichniy fenomen [Professional self-realization of the individual as a socio-psychological phenomenon]. Actualni problem psychologiy. (Vols. V.) 15. (pp. 82-92). Kyiv: GS Kostyuk Institute of Psychology NAPS of Ukraine [in Ukrainian].

2. Kuzmina N.V., Kuharev N.V. (1976) Psychologicheskaya structura deyatelnosty uchitelya [The psychological structure of the teacher's activity]. Gomel: GGU [in Russian]. 
3. Ziaziun, I.A. (Eds.). (1989). Osnovy pedagogicheskogo masterstva [Fundamentals of teaching excellence]. Moscow: "Prosveschenie" [in Russian].

4. Otych O.M. (2014) Osnovy pedagogichnoy maysternosty vykladacha profesiynoy schcoly [Fundamentals of teaching excellence of a vocational school teacher]. Kirovograd: Imex-LTD [in Ukrainian].

5. Ziaziun, I.A. (Eds.). (1997) Pedagogichna maysternist [Teaching excellence] Kyiv: Vyscha schoola [in Ukrainian].

6. Ziaziun, I.A. (Eds.). (2008) Pedagogichna maysternist [Teaching excellence] Kyiv: SPD Bogdanova A.M. [in Ukrainian].

7. Ziaziun, I.A. (Eds.). (2008) Pedagogichna maysternist [Teaching excellence]: anthology. Kyiv: SPD Bogdanova A.M. [in Ukrainian].

8. Professionalnaya samorealizacia lichnosty. [Professional self-realization of personality]. Personnel-Prestige website. Retrieved from https:/персонал-престиж.pф/\%D0\%BF\%D1\%80\% D0\%BE\%D1\%84\%D0\%B5\%D1\%81\%D1\%81\%D0\%B8\%D0\%BE\%D0\%BD\%D0\%B0\%D0\%BB\%D1/ 